ISSN : 2252-3839 (Print)

ISSN : 2549-2403 (On Line)

DOI : 10.28989/compiler.v9i1.656

http://ejournals.stta.ac.id/index.php/compiler/

\title{
IMPLEMENTATION OF GENETIC ALGORITHM IN COLLEGE SCHEDULING SYSTEM FTTI UNJANI YOGYAKARTA
}

\author{
Andika Bayu Saputra
}

Jurusan S-1 Teknik Informatika, Fakultas Teknik dan Teknologi Informasi Universitas Jenderal Achmad yani Yogyakarta J1. Siliwangi KM 0,7 Ringroad Barat Banyuraden

Gamping Sleman

Email : dika.putra21@gmail.com

\begin{abstract}
Scheduling lectures at academic institutions especially the Faculty of Engineering and Information Technology General Achmad Yani University Yogyakarta is still done semimanually with the help of Microsoft Excel and takes days to determine the days and space and hours of lectures, while in making schedules must be done optimally and fast because the schedule will be used for lecture activities each semester. In preparing lecture scheduling, it can be done by applying methods that are often used. One of them is using a genetic algorithm which is one of the right algorithms to solve complex search and optimization problems. Genetic algorithms can find the best solution from a broad set of candidates and have many optimum points. In other words, genetic algorithms provide solutions to scheduling problems to minimize collision schedules with coding stages, determine initial population values, determine chromosome values at random, determine fitness values for minimize the broken schedule, then select the roulette wheel, cross-move one-point crossover, then perform value coding mutations. This research is expected to be able to contribute knowledge about the application of genetic algorithms to overcome problems in the scheduling field. in the research system scheduling lectures can accelerate the creation of lecture schedules from chromosomes that have the best fitness value in this case the optimal value of cross-marriage probability used is 0.6 with a probability of 0.6 obtained the highest fitness value.
\end{abstract}

Keyword: Genetic Algorithms, scheduling system, lectures.

\section{Latar Belakang Masalah}

Penjadwalan perkuliahan pada instansi akademik khususnya Fakultas Teknik dan Teknologi Informasi Universitas Jenderal Achmad Yani Yogyakarta masih dilakukan secara semi-manual dengan bantuan Microsoft excel dan membutuhkan waktu berhari-hari untuk menentukan hari dan ruang serta jam perkuliahan, sedangkan dalam membuat jadwal harus dilakukan dengan optimal dan cepat dikarenakan jadwal akan dipergunakan untuk kegiatan perkuliahan tiap semesternya. Dalam penyusunan penjadwalan perkuliahan bisa dilakukan dengan menerapkan metode - metode yang sering digunakan. Salah satunya yaitu menggunakan algoritma genetika yang merupakan salah satu algoritma yang tepat untuk menyelesaikan masalah optimasi dan pencarian yang kompleks.

Algoritma genetika dapat mencari solusi terbaik dari kandidat set yang luas dan memiliki banyak titik optimum dengan kata lain algoritma genetika memberikan solusi terhadap permasalahan penjadwalan untuk meminimalisir jadwal yang tabrakan dengan tahapan pengkodean, menentukan nilai populasi awal, menentukan nilai kromosom secara acak, menentukan nilai fitness untuk meminimalisir jadwal yang tarbrakan, kemudian melakukan seleksi roulette wheel, melakukan pindah silang satu titik potong (one-point crossover), kemudian melakukan mutsi pengkodean nilai. Penelitian ini diharapkan dapat 
memberikan kontribusi ilmu pengetahuan tentang penerapan algoritma genetika untuk mengatasi permasalahan di bidang penjadwalan [1].

Penelitian dengan judul "Perancangan aplikasi penjadwalan mata kuliah" yang dilakukan oleh hartadi dan hidayat (2016) studi kasus STMIK Provisi Semarang. Penelitian ini membahas tentang penyusunan jadwal matakuliah dengan cara manual menggunakan aplikasi spreadsheet menjadi permasalahan yang membutuhkan ketelitian tinggi, karena harus memperhatikan kendala-kendala dalam penjadwalan (ruangan, dosen, kelompok mahasiswa, hari dan waktu) agar tidak saling bertumbukan. Permasalahan dalam penyusunan jadwal dapat diselesaikan menggunakan aplikasi penjadwalan matakuliah yang mampu membangkitkan jadwal secara otomatis menggunakan algoritma genetic serta menggunakan metode pengeditan jadwal Tarik-lepas (drag and drop) melalui GUI (graphical User Interface)[2].

Penelitian lain yang serupa, "Penjadwalan Mata Kuliah Menggunakan Algoritma Genetika di Jurusan Sistem Informasi ITS" dilakukan oleh Puspaningrum, Djunaidy dan Vinarti (2013). Penelitian tersebut menitikberatkan pada course object kode matakuliah, kelas, pertemuan, kode dosen1, kode dosen2, sks, dan semester. Course object tersebut digunakan untuk memecah kromosom menjadi dua jenis. Sedangkan batasan pada penelitian belum dapat terpenuhi oleh aplikasi dalam menghasilkan jadwal yang baik [3].

Dari sejumlah penelitian yang di pelajari dan ditinjau, untuk Implementasi Algoritma Genetika pada penjadwalan perkuliahan di FTTI Unjani Yogyakarta. Pada penelitian ini dengan batasan yang digunakan telah bisa menghasilkan penjadwalan yang baik. Hasil dari parameter yang telah ditentukan dan batasan yang telah di identifikasi mampu membantu dalam membuat penjadwalan dengan cepat. Sistem yang dikembangkan menggunakan framework CodeIgniter dan database MySQL.

\section{Metodologi Penelitian}

Penelitian ini bermula dengan melakukan telaah pada permasalahn yang akan diselesaikan kemudian melakukan analisis dan pemetaan solusi dengan menggunakan sumber daya yang sesuai dan tersedia. Penelitian ini akan dirancang dan dibangun sebuah system penjadwalan perkuliahan dengan memanfaatkan algoritma genetika. Metode penelitian yang digunakan adalah metode penelitian System Development Life Cycle (SDLC) model waterfall. Hasil dari penelitian ini diharapkan dapat memberikan kontribusi ilmu pengetahuan mengenai implementasi algoritma genetika pada system penjadwalan perkuliahan di Fakultas Teknik dan Teknologi Informasi Universitas Jenderal Achmad Yani Yogyakarta[4].

Implementasi algoritma genetika pada sistem penjadwalan perkuliahan pada penelitian ini terdiri dari dua tahapan yaitu tahapan pembentukan populasi awal dan tahapan proses algoritma genetika. Pada tahapan pembentukan populasi awal terdiri dari beberapa kromosom yang terbentuk atas beberapa gen. kromosom terdiri atas gen dosen, gen matakuliah, gen ruangan, gen jam dan gen hari.

Pada tahapan pembentukan populasi awal diperhatikan juga jumlah kromosom yang terdapat pada populasi awal adalah sebesar jumlah kelas yang telah direncanakan untuk semester yang sedang berjalan. Selanjutnya setelah populasi awal telah diketahui maka masuk ke tahap ke dua yaitu proses implementasi algoritma genetika yang di awali dengan mengambil populasi awal yang telah dibentuk. Algoritma genetika akan melakukan perulangan yang disebut sebagai generasi untuk menemukan kromosom dengan solusi terbaik. Setiap generasi akan dilakukan 3 tahapan seleksi yaitu seleksi kromosom, crossover dan mutasi sehingga menghasilkan sebuah populasi baru. 
Perulangan yang dilakukan oleh algoritma genetika akan menghasilkan generasi, proses regenerasi tersebut dibagi menjadi 2 kondisi untuk menghentikan proses regenerasi. Kondisi pertama yang biasa disebut dengan kondisi convergence yaitu kondisi dimana kromosom memenuhi nilai objektifitas yang sama dalam hal ini adalah jadwal yang sesuai dengan dosen, matakuliah, ruangan, jam dan hari. Sedangkan kondisi kedua adalah maksimal generasi yaitu kondisi dimana regenerasi akan berhenti apabila telah memenuhi batas jumlah generasi yang dibangkitkan [5].

\subsection{Batasan Penjadwalan}

Pada penelitian ini ada 2 batasan yang harus diperhatikan dalam menentukan penjadwalan pada perkuliahan dilingkungan FTTI UNJANI Yogyakarta. Batasan tersebut terdiri dari batasan kaku (hard constraints) dan batasan lunak (soft constraints) [6]. Fungsi batasan tersebut adalah untuk memberikan aturan / ruang lingkup pemanfaatan algoritma genetika dalam hal ini kasus penjadwalan di lingkungan FTTI UNJANI Yogyakarta. Untuk batasannya dijabarkan sebagai berikut:

1. Batasan kaku (hard constraints) terdiri dari:

a) Matakuliah untuk 3 dan 4 SKS diadakan sebanya dua kali dalam seminggu dan diusahakan tidak diadakan dalam satu hari sekaligus

b) Slot waktu pengajaran setiap harinya adalah empat kali perkuliahan dalam ruang yang sama dengan menggunakan kombinasi sks untuk lama waktu pengajaran. Kombinasi sks yang digunakan yaitu 1 sks, 3 sks, 2 sks, dan 4 sks.

c) Dosen yang sama tidak dapat mengajar matakuliah yang berbeda dalam waktu yang bersamaan.

2. Batasan lunak (soft constraints) terdiri dari:

a) Matakuliah yang diadakan secara parallel dengan dosen yang sama, sebaiknya tidak dijadwalkan dalam waktu yang bersamaan dan/atau berurutan agar materi yang akan diberikan dapat secara maksimal tersampaikan oleh dosen.

b) Matakuliah dengan kelas yang hanya satu (tidak parallel) yang diambil oleh angakatan yang sama sebaiknya tidak dilaksanakan dalam waktu yang bersamaan.

Pada penelitian ini dibangun dengan menggunakan framework CodeIgniter dengan Bahasa pemograman PHP dan database MySQL. Sampel studi kasus yang digunakan adalah memanfaatkan data semester ganjil 2018/2019 pada program studi S1 Informatika Fakultas Teknik dan Teknologi Informasi Unjani Yogyakarta. Untuk data dosen, data matakuliah, data rungan, data jam dan hari perkuliahan terlihat pada tabel 1.

Tabel 1. Data Dosen prodi S1 Informatika

\begin{tabular}{|l|c|l|l|}
\hline ID & NIDN & \multicolumn{1}{|c|}{ Nama Dosen } & \multicolumn{1}{|c|}{ Email } \\
\hline 01 & - & Andika Bayu Saputra, S.Kom., M.Kom & andika@unjaya.ac.id \\
\hline 02 & - & Ari Cahyono, S.Si,. M.T & arca@unjaya.ac.id \\
\hline 03 & - & Adri Priadana, S.Kom., M.Cs & adri@unjaya.ac.id \\
\hline 04 & - & Puji Winar Cahyo, S.Kom., M.Cs & pwcahyo@ unjaya.ac.id \\
\hline 05 & - & Muhammad Habibi, S.Kom., M.Cs & habibi@unjaya.ac.id \\
\hline 06 & - & Agung priyanto, S.T., M.Eng. & agung@unjaya.ac.id \\
\hline 07 & - & Landung Sudarmana, S.T., M.Kom & landung@unjaya.ac.id \\
\hline 09 & - & Eko Dwi Nugroho, S.Kom. M.Cs & ekodw@unjaya.ac.id \\
\hline 10 & - & Kartikadyota Kusumaningtyas, S.Pd., M.Cs & kartika@ unjaya.ac.id \\
\hline
\end{tabular}


Pada tabel 1 tersebut merupakan data dosen yang berhomebase pada prodi informatika. Untuk dosen lainnya yang berhomebase pada prodi lainnya yaitu prodi S1 Sistem Informasi, prodi S1 Teknologi Informasi, Prodi D3 Sistem informasi juga mengajar pada prodi S1 Informatika sehingga data total dosen yang mengajar sebanyak 21 orang dosen dengan rumpun keilmuan sesuai dengan bidang prodi. Sedangkan untuk data matakuliah yang berjalan pada semester ganjil 2018/2019 sebanyak 25 matakuliah seperti terlihat pada tabel 2 .

Tabel 2. Data matakuliah

\begin{tabular}{|c|c|c|c|}
\hline Semester & Kode & Nama Matakuliah & SKS \\
\hline $\mathrm{I}$ & CE112 & Pengantar Teknologi Informasi dan Komunikasi & 2 \\
\hline $\mathrm{I}$ & CA121 & Praktikum Aplikasi Komputer I & 1 \\
\hline $\mathrm{I}$ & CE214 & Konsep Pemrograman & 4 \\
\hline I & PS112 & Pengantar Rekayasa Software & 2 \\
\hline I & SD112 & Design Thinking & 2 \\
\hline $\mathrm{I}$ & SC343 & Bahasa Inggris I & 3 \\
\hline $\mathrm{I}$ & UN012 & Pendidikan Agama & 2 \\
\hline $\mathrm{I}$ & SC112 & Logika Informatika & 2 \\
\hline $\mathrm{I}$ & UN112 & Pendidikan Pancasila & 2 \\
\hline III & CE234 & Pemrograman Berorientasi Obyek & 4 \\
\hline III & CE424 & Pengembangan Aplikasi Web & 4 \\
\hline III & IY114 & Sistem Manajemen Basis Data & 4 \\
\hline III & SC143 & Diskrit dan Kombinatorika & 3 \\
\hline III & CR123 & Arsitektur Komputer \& Sistem Operasi & 3 \\
\hline III & SD123 & Konsep dan Strategi Disain Software & 3 \\
\hline V & CE244 & Pemrograman Terdistribusi Client/Server & 4 \\
\hline $\mathrm{V}$ & IY134 & Data Warehouse \& Big Data & 4 \\
\hline $\mathrm{V}$ & SE112 & Fundamental Sekuriti & 2 \\
\hline $\mathrm{V}$ & PS223 & Analisis dan Disain Software 2 & 3 \\
\hline V & UN213 & Bahasa Indonesia & 3 \\
\hline $\mathrm{V}$ & IC132 & Isu sosial dan etika dalam komputasi & 2 \\
\hline V & & Pilihan 2 & \\
\hline $\mathrm{V}$ & IN124 & * Sistem Pendukung Keputusan dan Sistem Pakar & 4 \\
\hline $\mathrm{V}$ & PS124 & * Rekayasa Software & 4 \\
\hline VII & SC634 & Komunikasi Interpersonal & 4 \\
\hline VII & CE624 & Proyek Pengembangan Software 2 & 4 \\
\hline VII & SC644 & Technopreneurship & 4 \\
\hline
\end{tabular}

Untuk data ruangan terdiri dari ruangan teori/kelas sebanyak 9 ruangan dan 3 laboratorium seperti terlihat pada tabel 3 berikut ini. 
Tabel 2. Ruang perkuliahan

\begin{tabular}{|l|l|c|l|}
\hline \multicolumn{1}{|c|}{ ID } & Ruangan & Kapasitas & \multicolumn{1}{c|}{ Jenis } \\
\hline L21 & 2A & 60 & Ruang Teori \\
\hline L22 & 2B & 60 & Ruang Teori \\
\hline L23 & 2C & 40 & Ruang Teori \\
\hline L24 & 2D & 30 & Ruang Teori \\
\hline L25 & 2E & 40 & Ruang Teori \\
\hline L26 & 2F-1 & 20 & Ruang Teori \\
\hline L27 & 2F-2 & 20 & Ruang Teori \\
\hline L28 & 2G & 30 & Ruang Teori \\
\hline L29 & 2H & 35 & Ruang Teori \\
\hline L31 & LAB 3A & 50 & Ruang Praktikum \\
\hline L32 & LAB 3B & 40 & Ruang Praktikum \\
\hline L33 & LAB 3C & 30 & Ruang Praktikum \\
\hline
\end{tabular}

Sedangkan untuk data waktu berlansungnya perkuliahan dimulai dari jam $08.00-16.00$ disesuaikan dengan jumlah sks matakuliah. Waktu hari berlangsungnya perkuliahan adalah 5 hari kerja dimulai dari hari senin - jumat. Matakuliah dengan sks 1 dan 2 jumlah pertemuanya dalam seminggu adalah 1 kali. Sedangkan untuk sks 3 dan 4 jumlah pertemuannya 2 kali dalam seminggu. Untuk jam perkuliahan seperti terlihat pada tabel 4.

Tabel 3. Jam pelaksanaan Matakuliah

\begin{tabular}{|c|c|c|c|c|}
\hline ID & Mulai & Selesai & Range & SKS \\
\hline 1 & 08.00 & 08.50 & $08.00-08.50$ & 1 \\
\hline 2 & 08.00 & 09.50 & $08.00-09.50$ & 2 \\
\hline 3 & 08.00 & 10.50 & $08.00-10.50$ & 3 \\
\hline 4 & 08.00 & 11.50 & $08.00-11.50$ & 4 \\
\hline
\end{tabular}

Pada 5 variabel (genetika) yang dilakukan penggabungan menjadi sebuah kromosom seperti terlihat pada tabel 5 .

Tabel 5. Contoh Hasil kromosom

\begin{tabular}{|c|c|c|c|c|}
\hline Id_dosen & Id_matakuliah & Id_ruang & Id_jam & Id_hari \\
\hline 01 & 5 & L21 & 2 & 3 \\
\hline
\end{tabular}

Pada tabel 5 dapat dijelaskan maksud dari kromosom tersebut adalah dosen dengan nama Andika Bayu Saputra, S.Kom. M.Kom. mengajar Design Thinking di ruang perkuliahan 2A jam 08.00 - 9.50, 2 SKS pada hari Rabu.

\subsection{Implementasi pada sistem.}

Sistem yang dikembangkan pada penelitian ini menggunakan algoritma genetika, dimana proses penjadwalannya dilakukan secara otomatis. Bila terjadi tabrakan jadwal, 
sistem yang dikembangkan akan mencari secara otomatis dan terus menerus jadwal yang paling optimal.

Pada sistem penjadwalan perkuliahan ini dilakukan tahapan untuk penyelesaian permasalahan penjadwalan dengan mengimplementasikan algoritma genetika. Dimulai dari preprocessing data, set populasi dan iterasi, inisialisasi populasi, persiapan penjadwalan, penjadwalan, penjadwalan memiliki fitness kecil dan menampilkan hasil penjadwalan. Seperti terlihat pada gambar 1.

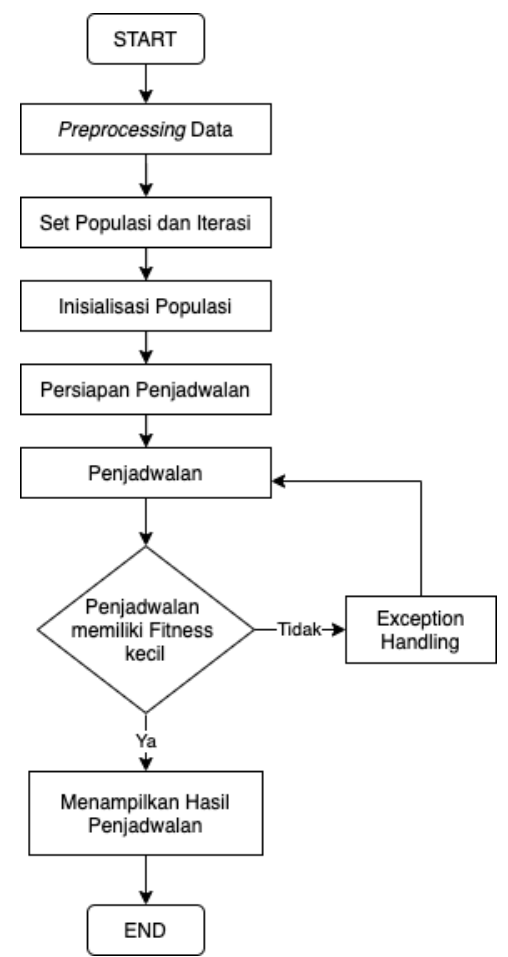

Gambar 1. Langkah pembuatan penjadwalan menggunakan algoritma genetika.

\subsection{DFD Sistem}

Secara umum, alur data pada sistem yang dikembangkan akan tampak seperti pada gambar 2. Proses pengelolaan data yang dilakukan oleh system informasi penjadwalan kuliah akan menghasilkan penjadwalan dengan menggunakan metode algoritma genetika.

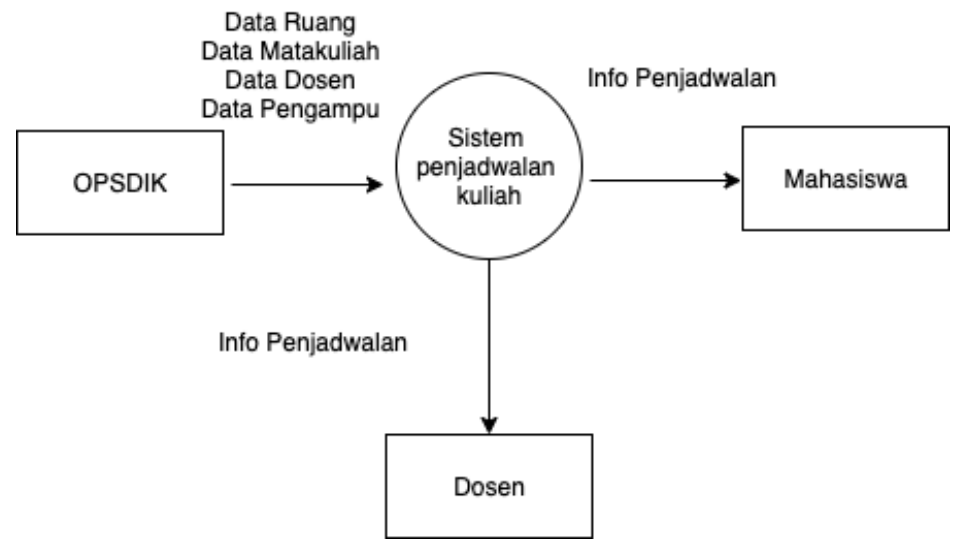

Gambar 2. DFD Level 0

Untuk memperjelas proses DFD level 0, maka proses yang lebih rinci dapat dilihat seperti pada gambar 3. pada DFD level 1 dijabarkan lebih detail tentang proses penjadwalan 
kuliah dengan menggunakan algoritma genetika. Data yang digunakan untuk mendukung sistem pertama kali di inputkan oleh opsdik seperti data hari, jam dan ruangan yaitu pada master data. Sedangkan data dosen dan pengampu diinputkan setelah master data diinputkan terlebih dahulu.

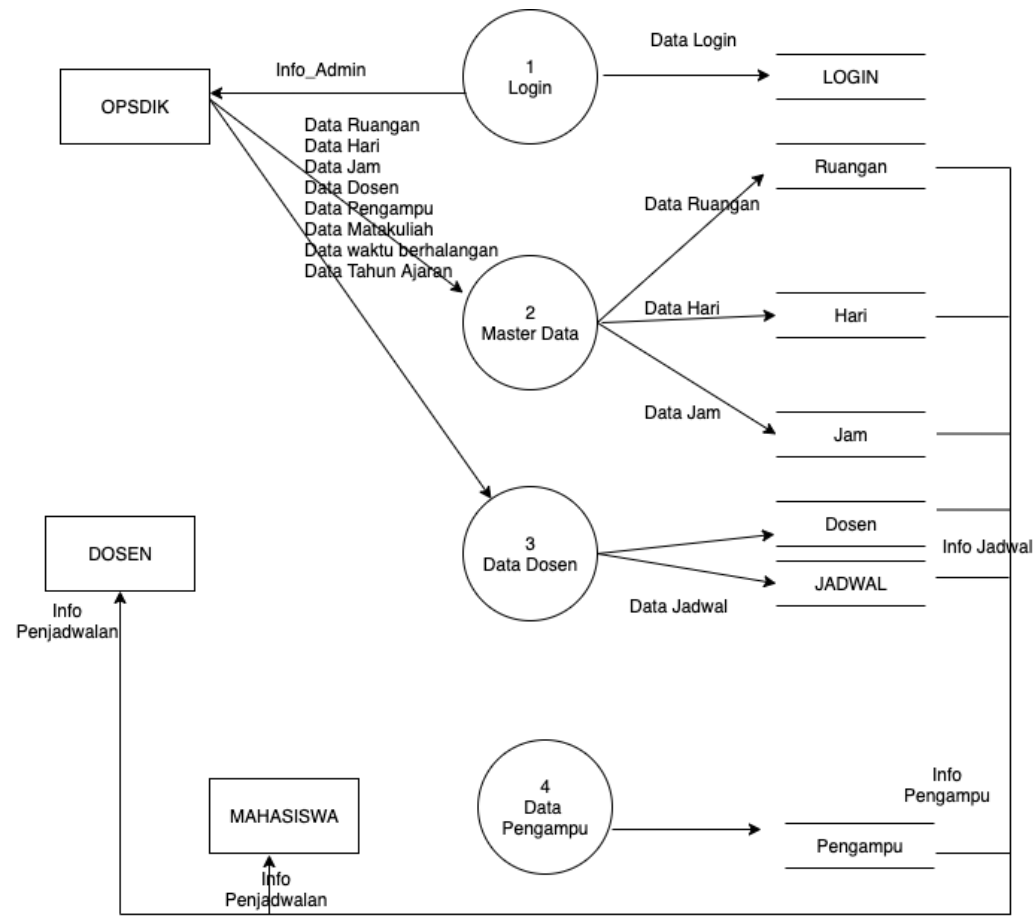

Gambar 3. DFD level 1 sistem penjadawalan kuliah

\section{Hasil dan Pembahasan}

Pada sistem penjadwalan perkuliahan terdiri dari modul master data sistem yang digunakan untuk memenuhi data di awal sebelum sistem digunakan / di akses oleh pengguna lainnya. Menu yang ada pada master data seperti menu hari, jam dan waktu berhalangan. Pada menu hari digunakan untuk menentukan hari berlangsungnya perkuliahan. Sedangkan pada menu jam digunakan untuk menentukan waktu perkuliahan. Khusus untuk menu waktu berhalangan digunakan untuk memberikan keterangan dosen yang berhalangan di waktu dan jam tertentu dikarenakan rapat rutin fakultas. Untuk menu master data terlihat seperti gambar 4.

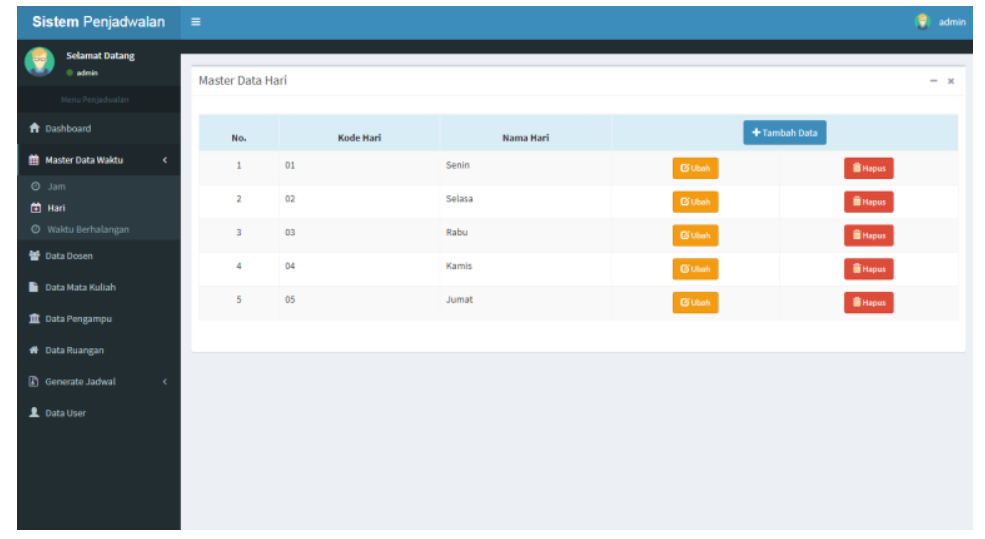

Gambar 4. Menu master data 
Untuk menentukan data awal selanjutnya di buatkan menu dosen yang berisi tentang dosen yang terdapat dilingkungan FTTI Unjani Yogyakarta. Pada menu dosen terdiri dari menu tambah dosen yang menyediakan form untuk menambah dosen yang baru. Pada menu dosen terlihat seperti pada gambar 5 .

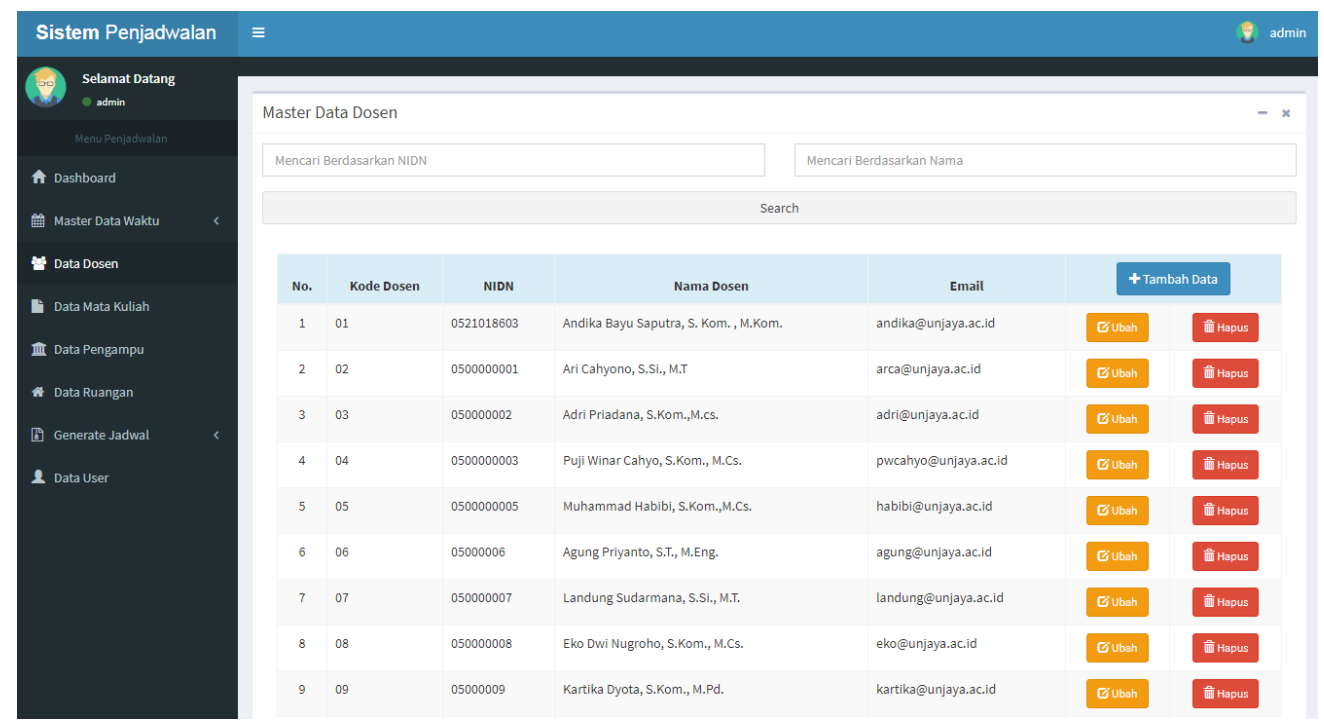

Gambar 5. Menu data dosen

Sedangkan untuk menu awal yang harus diinputkan data terlebih dahulu adalah data matakuliah. Pada menu data matakuliah disikan semua mata kuliah yang ada pada prodi seperti terlihat pada gambar 6 .

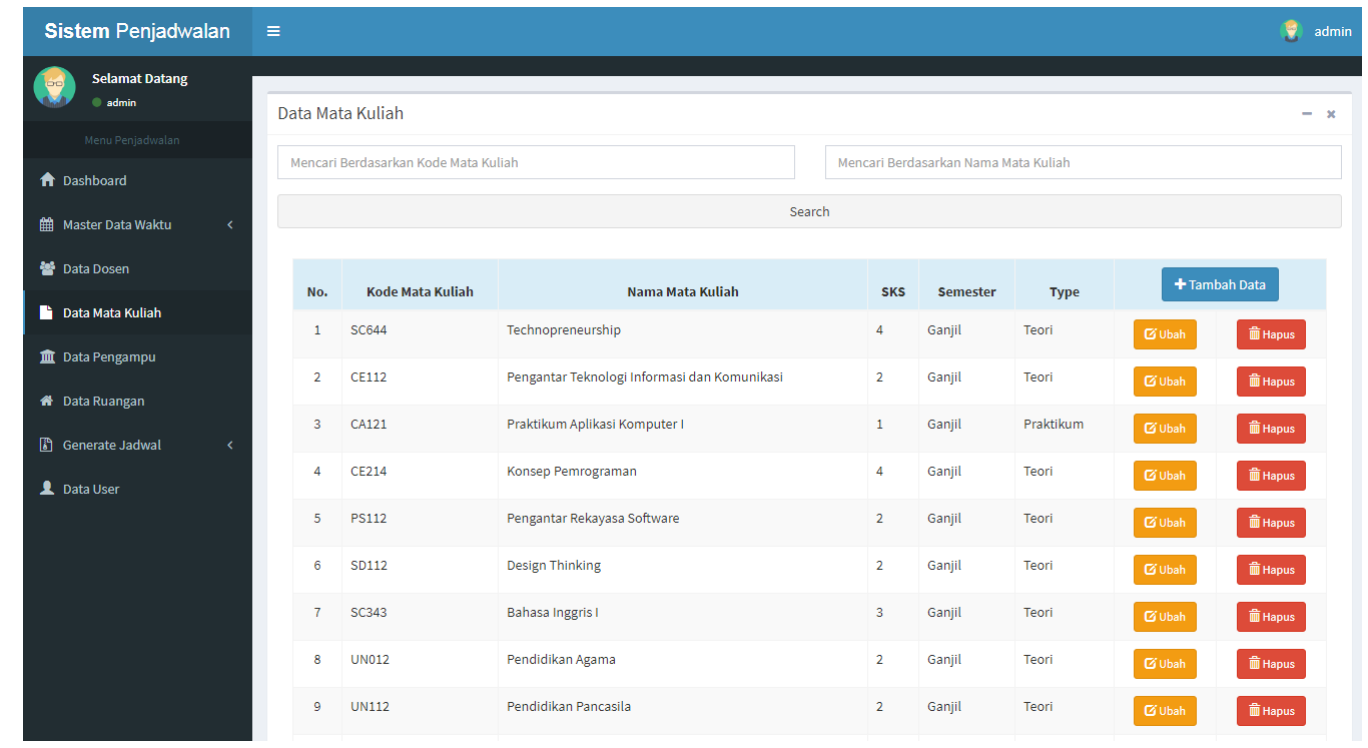

Gambar 6. Menu data Matakuliah

Menu selanjutnya yang digunakan untuk pengaturan awal sistem adalah menu ruangan yang berisikan data ruangan yang tersedia pada FTTI Unjani Yogyakarta. Menu ini digunakan untuk pengaturan ruangan dan kapasitas yang ada termasuk pada identifikasi ruang laboratorium. Untuk menu ruangan terlihat pada gambar 7. 


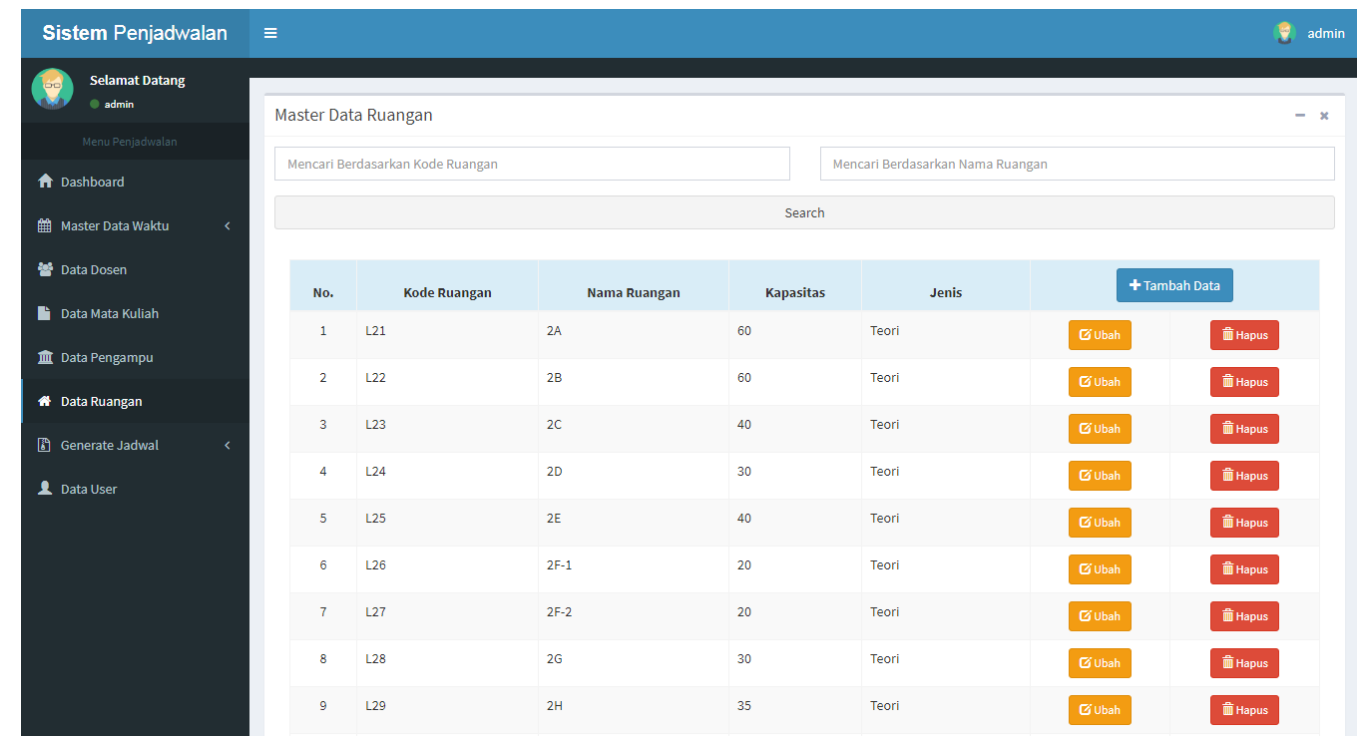

Gambar 7. Menu Ruangan

Pada menu selanjutnya yaitu menu data pengampu merupakan menu yang digunakan untuk pengaturan dosen siapa yang akan mengajar matkuliah apa. Menu data pengampu digunakan untuk pengaturan awal penentuan bidang dosen yang berkaitan dengan matakuliah yang akan diajarkan seperti terlihat pada gambar 8 .

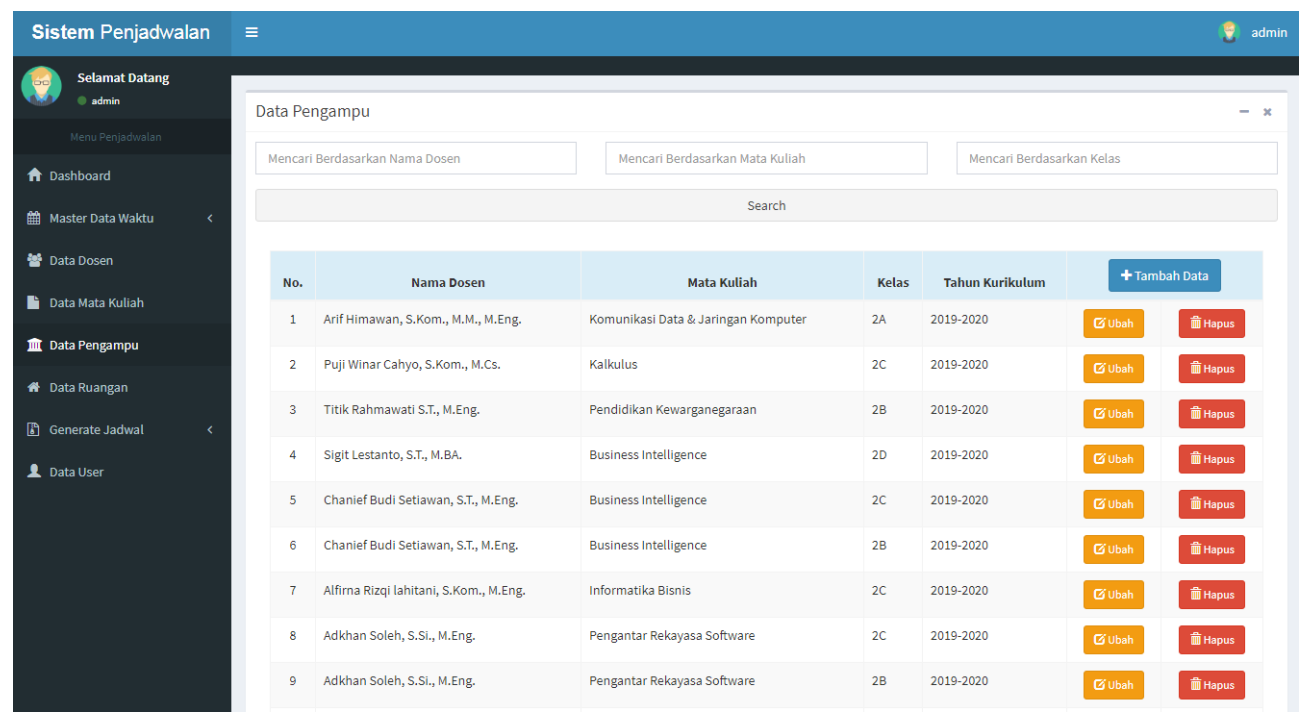

Gambar 8. Menu data pengampu

Khusus untuk modul penjadwalan terdiri dari 2 menu yaitu menu input generate jadwal dan hasil generate jadawal. Pada input generate jadwal digunakan default parameter genetika. Adapaun default aplikasi memiliki kombinasi parameter dapat dilihat pada tabel 6 .

Tabel 6. Kombinasi default parameter gentika

\begin{tabular}{|l|c|}
\hline Generasi & 200 \\
\hline Populasi & 10 \\
\hline Perkawinan Silang & 0,5 \\
\hline
\end{tabular}




\begin{tabular}{|l|c|}
\hline Mutasi & 0,1 \\
\hline
\end{tabular}

Pada sistem penjadwalan perkuliahan ini disiapkan menu untuk generate jadwal dengan mengisikan pilihan yaitu tahun akademik dan semester. Sedangkan untuk masukan nilai pembangkitan nilai kromosom dan nilai maksimal generasi ditentukan dari sistem dengan memilih opsi yang telah disediakan. Untuk nilai perkawinan silang (crossover) dan nilai mutasi di inputkan manual seperti terlihat pada gambar 9.

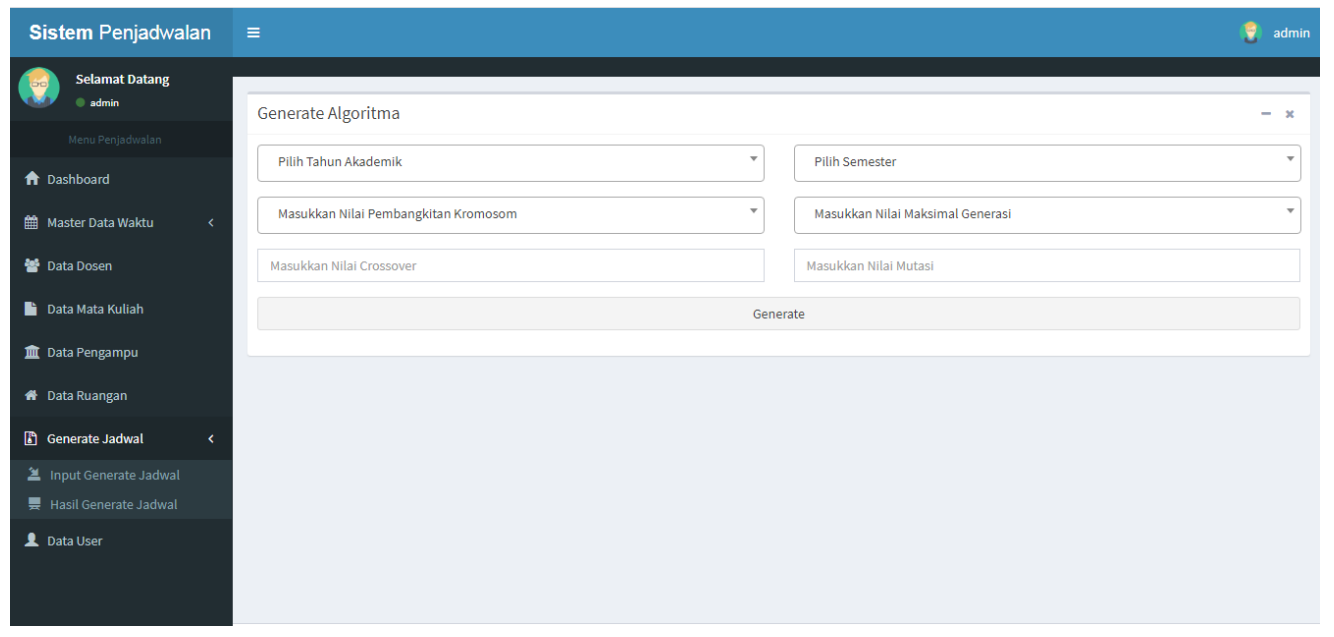

Gambar 9. Generate jadwal

Setelah input generate jadwal dilakukan maka langsung beralih ke menu hasil generate jadwal yang digunakan untuk melihat hasil generate jadwal dengan menggunakan algoritma genetika seperti terlihat pada gambar 10 .

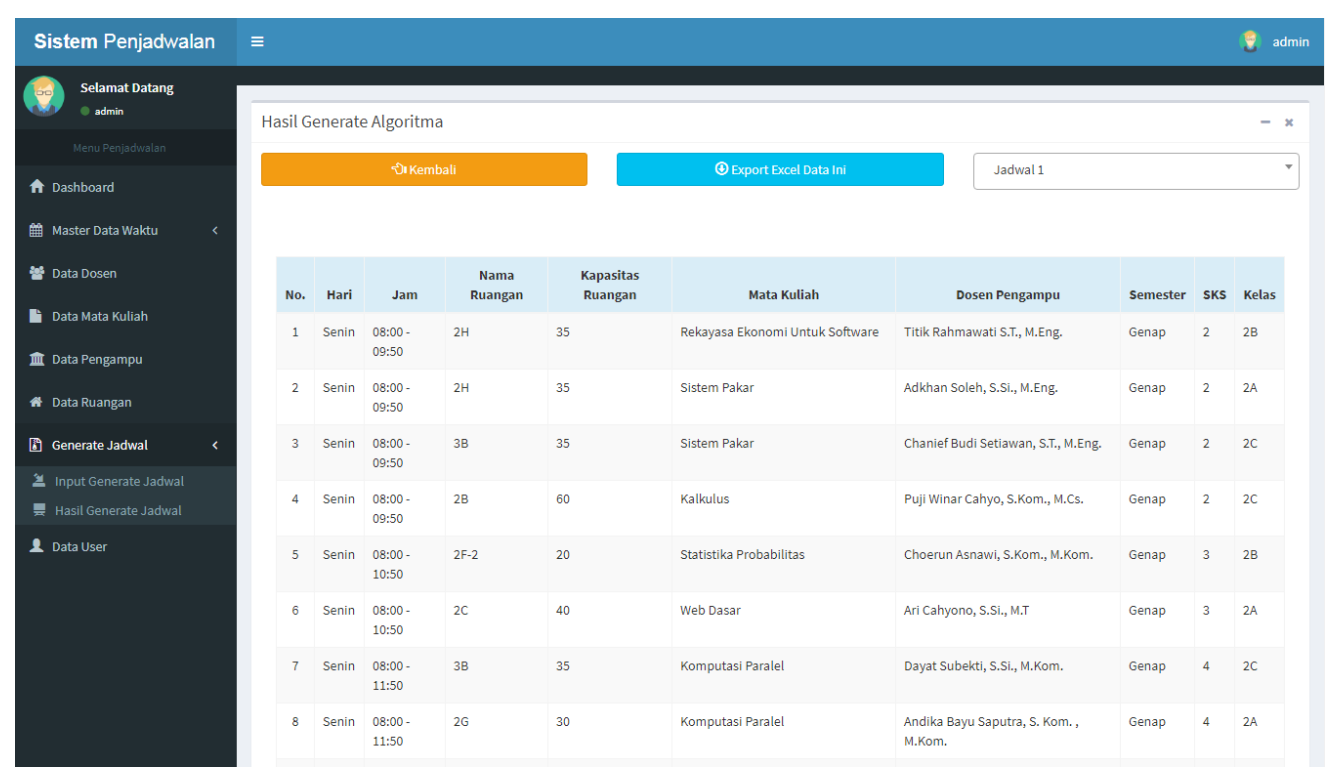

Gambar 10. Hasil generate jadwal 
Pada menu hasil generate jadwal terlihat jadwal yang telah di buat menggunakan algoritma genetika dengan parameter yang telah ditentukan. Untuk kepentingan pelaporan dibuat jaga export data excel seperti terlihat pada gambar 11.

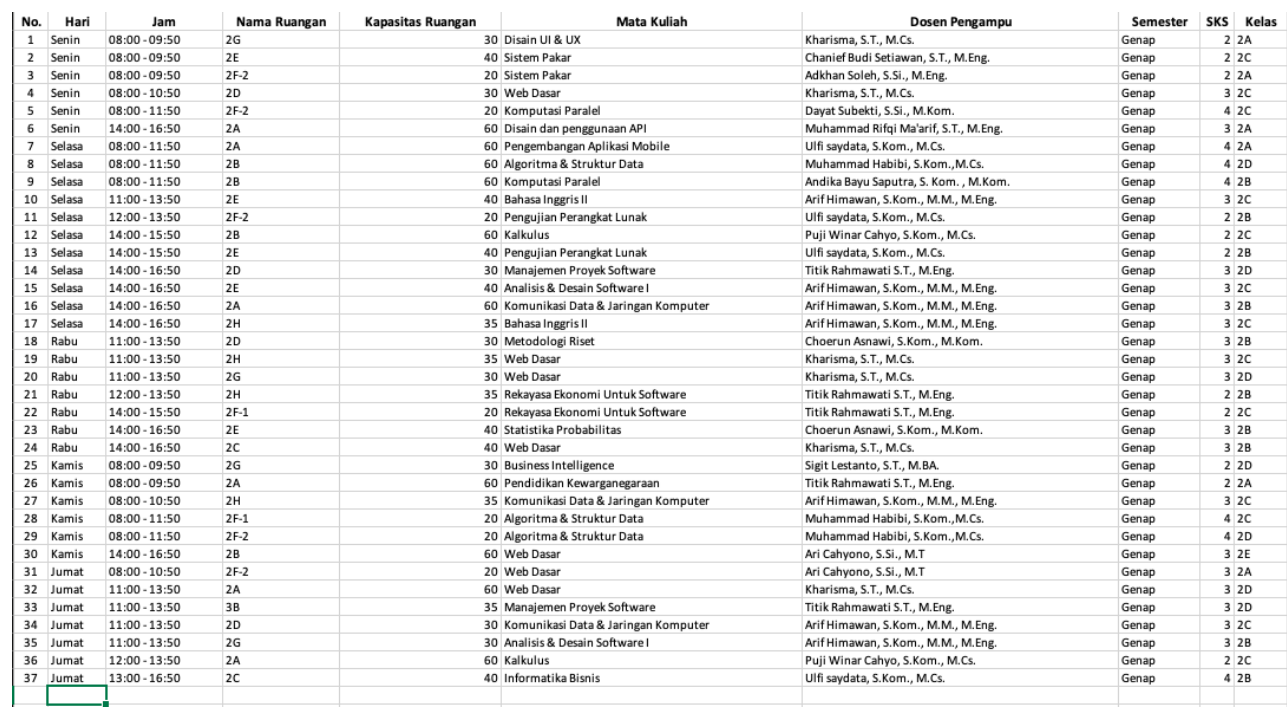

Gambar 11. Hasil export excel penjadwalan perkuliahan

\section{Kesimpulan} berikut:

Berdasarkan penelitian yang telah dilakukan, maka diperoleh kesimpulan sebagai

a. Sistem informasi penjadwalan perkuliahan yang dibangun mampu membuat jadwal tanpa adanya jadwal yang bentrok.

b. Sistem penjadwalan perkuliahan ini mampu mengatur ulang jadwal jika ada dosen yang tidak bisa mengajar di waktu-waktu tertentu.

c. Sistem penjadwalan perkuliahan mempu mempercepat pembuatan jadwal perkuliahan dari kromosom yang memiliki nilai fitness terbaik pada kasus ini nilai probabilitas perkawinan silang yang optimal digunakan adalah 0,6, pada probabilitas 0,6 didapatkan nilai fitness tertinggi.

\section{Daftar Pustaka}

[1] Saputra, A.B. and Cahyono, A., (2018). Aplikasi Monitoring Capaian Kompetensi Peserta Didik Di SMA Kolombo Yogyakarta. Angkasa: Jurnal Ilmiah Bidang Teknologi, 10(2), pp.172-179.

[2] Hartadi, R., \& Hidayat, A. (2016). Perancangan Aplikasi Penjadwalan Mata Kuliah (Studi Kasus: STMIK Provisi Semarang). Bianglala Informatika, 4(1).

[3] Josi, A. (2017). Implementasi Algoritma Genetika Pada Aplikasi Penjadwalan Perkuliahan Berbasis Web Dengan Mengadopsi Model Waterfall (Studi Kasus: STMIK Prabumulih). Jurnal Informatika: Jurnal Pengembangan IT, 2(2), 77-83.

[4] Suwirmayanti, N. L. G. P., Sudarsana, I. M., \& Darmayasa, S. (2016). Penerapan Algoritma Genetika Untuk Penjadwalan Mata Pelajaran. Journal of Applied Intelligent System, 1(3), 220-233. 
[5] Paranduk, L. et al. (2018) .Sistem Informasi Penjadwalan mata kuliah menggunakan algoritma genetika berbasis Web. in, pp. 46-50.

[6] Puspaningrum, W. A., Djunaidy, A., \& Vinarti, R. A. (2013). Penjadwalan Mata Kuliah Menggunakan Algoritma Genetika di Jurusan Sistem Informasi ITS. Jurnal Teknik ITS, 2(1), A127-A131.

[7] Suhartono, E. (2015). Optimasi Penjadwalan Mata Kuliah dengan Algoritma Genetika (Studi Kasus di AMIK JTC Semarang). INFOKAM, 11(5).

[8] Suprayogi, D. A., \& Mahmudy, W. F. (2015). Penerapan algoritma genetika traveling salesman problem with time window: Studi kasus rute antar jemput laundry. Jurnal Buana Informatika, 6(2).

[9] Yudistira, A., Djamal, E. C., \& Yuniarti, R. (2017, August). Optimalisasi Penjadwalan Audit di Inspektorat Daerah Kabupaten Cianjur Menggunakan Algoritma Genetika. In Seminar Nasional Aplikasi Teknologi Informasi (SNATI). 